\title{
A educação em nível primário da professora Isabel Doraci Cardoso (1940-1944): uma história da educação vista de baixo
}

The elementary education of Professor Isabel Doraci Cardoso (1940-1944):

a history of education seen from below

La educación a nivel primario de la profesora Isabel Doraci Cardoso (1940-1944):

una historia de la educación vista desde abajo

RAYLANE ANDREZA DiAS NAVARRO BARRETO ${ }^{1}$

\section{Resumo}

Em Sergipe, as Escolas Isoladas eram instituições escolares onde a maioria dos sertanejos sergipanos cursava a educação primária. A professora Isabel Doraci Cardoso (86 anos), representando bem a tradição interiorana, fez o seu curso primário entre o final dos anos de 1930 e meados de 1940 nesse tipo de escola. Este trabalho - com base no conceito de experiência de Edward Palmer Thompson (1981), na noção de cultura escolar de Dominique Julia (2001) e a partir de uma abordagem da história vista de baixo, de Jim Sharpe (1992) propõe-se tratar sobre o processo de formação escolar da referida professora, estabelecendo as fronteiras entre as condições materiais e educacionais experienciadas e reveladas por sua narrativa, que se constituiu fonte e objeto de análise. Os dados revelam, em termos conclusivos, que esse tipo de narrativa contribui para o entendimento de uma pluralidade de circunstâncias que configuram e colaboram com a escrita da história.

Palavras-chave: Educação primária. Educação de mulheres. Experiência formativa e (auto)formativa.

\footnotetext{
${ }^{1}$ Doutora em Educação pela Universidade Federal do Rio Grande do Norte, com estágio de pós-doutorado realizado na Universidade de Lisboa. Professora do Programa de Pós-Graduação em Educação da Universidade Tiradentes. E-mail: raylanenavarro@bol.com.br
} 


\begin{abstract}
In Sergipe, the Isolated Schools were school institutions where most Sergipean inlander attended elementary education. Professor Isabel Doraci Cardoso (86 years old), well representing the interior tradition, did her elementary course between the late 1930s and the mid-1940s in this type of school. This work - based on the concept of experience of Edward Palmer Thompson (1981), in the notion of school culture of Dominique Julia (2001) and from an approach of history seen from below, of Jim Sharpe (1992) - proposes to deal with the educational process of the said teacher, establishing the boundaries between the material and educational conditions experienced and revealed by her narrative, which was the source and object of analysis. The data reveal, in conclusive terms, that this type of narrative contributes to the understanding of a plurality of circumstances that shape and collaborate with the writing of history.
\end{abstract}

Keywords: Elementary education. Education of women. Formative and (self) formative experience.

\title{
Resumen
}

En Sergipe, las Escuelas Aisladas eran instituciones escolares donde la mayoría de los campesinos de Sergipe cursaban la educación primaria. La profesora Isabel Doraci Cardoso (86 años), representando bien la tradición interiorana, hizo su curso primario entre el final de los años 1930 y mediados de 1940 en ese tipo de escuela. Este trabajo - basado en el concepto de experiencia de Edward Palmer Thompson (1981), en la noción de cultura escolar de Dominique Julia (2001) ya partir de un abordaje de la historia vista desde abajo, de Jim Sharpe (1992) - propone tratar sobre el proceso de formación escolar de dicha profesora, estableciendo las fronteras entre las condiciones materiales y educativas experimentadas y reveladas por su narrativa, que se constituyó fuente y objeto de análisis. Los datos revelan, en términos concluyentes, que ese tipo de narrativa contribuye al entendimiento de una pluralidad de circunstancias que configuran y colaboran con la escritura de la historia.

Palabras clave: Educación primaria. Educación de las mujeres. Experiencia formativa y (auto) formativa. 
Se isolarmos a evidência singular para um exame à parte, ela não permanece submissa, como a mesa, ao interrogatório: agita-se, nesse meio tempo, ante nossos olhos. Essas agitações, esses acontecimentos, se estão frequentes parecem chocar-se, lançar-se sobre, romper-se contra a consciência social existente. Propõem novos problemas e, acima de tudo, dão origem continuadamente à experiência (THOMPSON, 1978, p. 199).

\section{Introdução}

O conceito de experiência dá à história não somente um objeto de análise, mas, sobretudo, colabora com a história social na medida em que viabiliza os estudos culturais. Nesse sentido, a lógica histórica, posposta pelo historiador inglês Edward Palmer Thompson, tem na simbiose hipótese-evidência o desafio do historiador. Para esse autor, o objeto do conhecimento histórico está relacionado aos fatos ou evidências dotados de existência "real". Por isso, o conhecimento histórico, sob sua ótica, está condicionado às perguntas feitas às evidencias e elas, as perguntas, por sua vez, estão atreladas aos conceitos que as alicerçam e, nesse sentido, sua capacidade de alcance está limitada ao seu campo. Às evidencias, por sua vez, devem ser feitas perguntas, mas nem todas são respondidas e reverberam em uma teoria, pois as respostas também dependem de uma série de circunstâncias que podem desembocar em novos problemas e novas interpretações, mas nunca em uma mudança histórica.

“A interrogação e a resposta são mutuamente determinantes e a relação só pode ser compreendida como um diálogo [...]" (THOMPSON, 1981, p. 50), que visa ao conhecimento histórico, tendo por objeto uma "história real" cuja investigação parte da hipótese e conta com evidências "incompletas e imperfeitas", mas, ainda assim, capazes de revelar o acontecido numa lógica histórica. Na visão de Thompson (1981, p. 50) a partir de sua herança marxista, o conhecimento histórico dá-se “[...] na medida em que uma tese (ou conceito, ou hipótese) é posta em relação com suas antíteses (determinação objetiva não-teórica) e disso resulta uma síntese (conhecimento histórico)". A decorrência disso é a "dialética do conhecimento histórico". Isso porque as evidências históricas residem no conjunto de hipóteses adotadas e nas críticas pelas quais passam. Por isso mesmo, a tarefa do historiador é a de elucidar os processos do evento histórico, considerando seus princípios e suas tendências; e principalmente o fato de que não há "uma verdade", e que a lógica histórica pressupõe um conhecimento em desenvolvimento.

Vivemos, como admitiu Thompson (1978, p. 240), em um mesmo “[...] elemento (um presente tornando-se passado), um elemento humano de hábitos, necessidades, razões, vontades, ilusões, desejos, e deveríamos saber que ele é constituído de um material resistente". E é justamente para dar conta do elemento humano e apreendê-lo que ele concebe a categoria de experiência, esta por sua vez atrelada à categoria cultura, embora sejam inconfundíveis. Para ele

Toda teoria da cultura deve incluir o conceito da interação dialética entre cultura e algo que não é cultura. Devemos supor que a matéria-prima da 'experiência de vida' esteja em um dos pólos, e todos os infinitamente 
complexos sistemas e disciplinas humanos, articulados ou não, formalizados em instituições ou dispersos das maneiras menos formais que 'manejam', transmitem ou distorcem esta matéria-prima, estejam no outro pólo. É sobre este processo ativo, que é, ao mesmo tempo, o processo mediante o qual os seres humanos fazem sua história, que venho insistindo (THOMPSON, 1981, p. 398, grifos no original).

Assim, é justamente em busca do entendimento do "[...] processo mediante o qual os seres humanos fazem sua história" no campo da educação que tomo como fonte e objeto de análise a narrativa (ALBERTI, 2012) de história de vida da professora aposentada Isabel Doraci Cardoso, de 86 anos de idade, cuja experiência vivida conta, de um lado, com uma cultura escolar predeterminada e, de outro, com condições materiais de existência que ora limitam, ora condicionam práticas escolares que não somente a tornaram aluna mas também a formaram professora. Nesse sentido, atrelar a categoria experiência à educação, a partir da narrativa da história de vida da aluna que se tonou professora no agreste sergipano, não somente permite entender suas agruras, seus desejos, seus medos, suas possibilidades, suas habilidades e sua escolha mas também o que deles resultam. Oliveira (2008, p. 154), ao analisar "O pensamento de Edward Palmer Thompson como programa para a pesquisa em história da educação", tendo como fio condutor a função do historiador, conclui que um programa possível

[...] deveria levar em consideração o movimento interno de cada unidade escolar analisada em relação ao contexto social que extrapola os seus muros, por sua vez relacionado com uma lógica de sistema que preside a organização escolar em termos locais, nacionais e internacionais. Ao mesmo tempo precisaria reportar-se à história de vida e profissional dos diferentes sujeitos que se relacionam no interior daquelas culturas, bem como às motivações individuais, de grupos (corporação de professores, por exemplo), e das finalidades socioculturais que movimentam as nossas sociedades da escolarização. No caso dos professores, já na década de 1960, Thompson aludia a uma dimensão que fecundaria os estudos sobre a história social dos currículos e da profissão docente (OLIVEIRA, 2008, p. 154, grifo nosso).

É justamente nesse tempo que a aliança entre cultura escolar e experiência revela-se eficiente para a construção do conhecimento histórico. Isso porque a cultura escolar, para Julia (2001), contempla as normas e as práticas escolares:

Para ser breve, poder-se-ia descrever a cultura escolar como um conjunto de normas que definem conhecimentos a ensinar e condutas a inculcar, e um conjunto de práticas que permitem a transmissão desses conhecimentos e a incorporação desses comportamentos; normas e práticas coordenadas a finalidades que podem variar segundo as épocas (finalidades religiosas, sociopolíticas ou simplesmente de socialização). Normas e práticas não podem ser analisadas sem se levar em conta o corpo profissional dos agentes que são chamados a obedecer a essas ordens e, portanto, a utilizar dispositivos pedagógicos encarregados de facilitar sua aplicação, a saber, 
os professores primários e os demais professores. Mas, para além dos limites da escola, pode-se buscar identificar em um sentido mais amplo, modos de pensar e de agir largamente difundidos no interior de nossas sociedades, modos que não concebem a aquisição de conhecimentos e de habilidades senão por intermédio de processos formais de escolarização: aqui se encontra a escalada dos dispositivos propostos pela schooled society que seria preciso analisar; nova religião com seus mitos e ritos contra a qual Ivan Illich se levantou, com vigor, há mais de vinte anos. Enfim, por cultura escolar é conveniente compreender também, quando é possível, as culturas infantis (no sentido antropológico do termo), que se desenvolvem nos pátios de recreio e o afastamento que apresentam em relação às culturas familiares (JULIA, 2001, p. 10-11, grifo nosso).

A visão de Julia foi escrutinada por Faria Filho, Gonçalves, Vidal e Paulilo (2004) para demonstrar como o foco da história da educação foi ampliado com a inserção da cultura escolar e, consequentemente, das práticas escolares como objeto de análise e como campo de investigação. Nessa linha, também ganha relevo o sujeito escolar, seja aluno ou professor, cujas somas das práticas compõem a experiência, e esta, por sua vez, dá a ver o campo.

Quando Thompson estudou a formação da classe operária inglesa, por certo não pensava em educação; ao contrário, pensou em como entender uma classe que necessariamente deveria ser vista por baixo, e não, necessariamente, como os marxistas a concebiam, ou seja, a partir de uma teoria cuja realidade tinha de se adaptar. Como critico desse tipo de marxismo, Thompson, junto com outros historiadores ingleses, a exemplo de John Saville, George Rude, Rodney Hilton, Dorothy Thompson, Edmund Dell, Victor Kiernan, Maurice Dobb e Raphael Samuel, membros de uma confraria denominada "Grupo de Historiadores do Partido Comunista", criadores da New Left Review, inauguram uma nova forma de entender e de escrever a história (BARRETO, 2013). Desta feita, sob a condição de que uma hipótese seja comprovada com evidências reais e que a teoria seja seu resultado.

Nesse sentido, e por meio desses dois conceitos - experiência e cultura escolar trago à luz a educação escolar primária de Isabel Dorcaci Cardoso. Para tanto, sua narrativa como já anunciado, tomada como objeto e fonte, foi privilegiada, e associada a outras fontes escritas. Isso porque a fusão de fontes torna-se uma ação metodológica importante, pois, como afiança Alberti (1990), a fonte oral tem um potencial de revelar o vivido concebido por quem viveu e, assim, trazer à cena histórica elementos que, de outra forma, não poderiam ser computados na sua escrita. Para a autora, o grande potencial da fonte oral é permitir entender como as representações dos fatos se constituem.

Nesse mesmo sentido, a fonte oral, quando relata suas próprias experiências, em especial de formação, traz consigo, para além da representação do que viveu, traços da memória coletiva que podem, ou não, corroborar a expectativa ou as certezas do narrador. Assim, é pela experiência constituída de ações, na vida e no trabalho, com parentes, amigos, colegas, conhecidos e desconhecidos, que os sujeitos se constituem a ponto de, sobre si mesmos, poderem narrar. Afinal, 
[...] os valores não são 'pensados', nem 'chamados'; são vividos, e surgem dentro do mesmo vínculo com a vida material e as relações materiais em que surgem nossas idéias. São as normas, regras, expectativas etc. necessárias e aprendidas (e 'aprendidas' no sentimento) no 'habitus' de viver; e aprendidas, em primeiro lugar, na família, no trabalho e na comunidade imediata. Sem esse aprendizado, a vida social não poderia ser mantida e toda produção cessaria (THOMPSON, 1981, p. 194, grifo do autor).

Como pode ser entendido, aprendizado e vida social são duas faces da mesma moeda, cujo potencial analítico está justamente na sua relação simbiótica. Todas as experiências daí resultantes são dotadas de elementos reveladores da vida e do campo em que está inserida. Nesse sentido, para além dos valores, no caso especifico do campo da educação, a partir da experiência de um sujeito escolar, é possível perceber, dentre outros elementos, as representações da ambiência escolar, os cuidados com a criança, os contrapontos entre a educação familiar e a escolar, os elementos da cultura material, os métodos de ensino, a circulação e a apropriação de reformas escolares e as consequentes rupturas de modelos escolares, as distinções alcançadas ou não, bem como se a escola permite a movimentação de classe social dos sujeitos educados.

\section{Quem é Isabel Doraci Cardoso e por que ela é um sujeito histórico?}

Isabel Doraci Cardoso, filha do marceneiro Manoel Dias Cardoso Sobrinho e da dona de casa Maria José Cardoso, nasceu na cidade de Aquidabã, Estado de Sergipe, no dia $1^{\circ}$ de agosto de 1930. Teve uma infância comum aos seus contemporâneos. Em suas boas lembranças, usufruiu da infância com muitas brincadeiras. Fez parte de uma família tradicional, tendo o seu pai como chefe da casa e sua mãe como responsável por sua criação e a dos seus três irmãos. Aos cinco anos de idade, viu despertar dentro de si o desejo de frequentar a escola. O seu contato com as primeiras letras deu-se em uma Escola Isolada, que funcionava na sala de visitas da casa da própria professora. Os recursos desta escola eram mínimos, o que tornava impossível à professora oferecer um ambiente adequado aos alunos. A estrutura física da escola era precária, contando apenas com "tamboretes". O material didático era quase inexistente, tendo apenas o minimamente necessário. A didática das suas primeiras professoras, Pureza dos Reis e Donana, seguia o método sintético, contando ainda com a aplicação de castigos físicos e outras formas de punições para obter a ordem e a disciplina dos alunos.

Logo foi transferida dessa Escola Isolada para outra mais recomendada por todos na cidade, pois oferecia uma melhor estrutura aos alunos, embora fosse ainda precária quanto aos materiais didáticos. Não obstante, a estrutura física era mais condizente com um modelo escolar, pois oferecia aos alunos carteiras suficientes para acomodar todos, e um quadro negro para auxiliar nas atividades escolares. Aos sete anos de idade, ingressou no Grupo Escolar Milton Azevedo, sendo esta escola mais adequada que a outra, pois possuía recursos que viabilizavam o ensino dos alunos, na medida em que lhes oferecia materiais didáticos, como livros, mapas, globos terrestres e um ambiente com carteiras, mesas e quadros. A didática dos seus professores obedecia ao mesmo "ensino decorativo" oferecido nas Escolas Isoladas; no 
entanto, ali, segundo ela, não era permitido o uso dos castigos físicos como recurso para disciplinar os alunos que apresentassem mau comportamento. Aos 14 anos de idade, concluiu a $4^{\text {a }}$ série primária, mas, por sua família não possuir condições financeiras que garantissem a continuidade de seus estudos na capital do Estado, lugar mais próximo que oferecia o ginásio, interrompeu a sua vida estudantil, e deu início a uma vida doméstica, ajudando sua mãe nos afazeres da casa.

Somente 14 anos depois (1958), foi criado o ginásio no munícipio de Aquidabã. No entanto, por se considerar "velha demais" (já estava com 28 anos de idade) para voltar a estudar, relutou para retomar seus estudos. Mas ao saber que sua primeira professora também iria voltar a estudar, sentiu-se motivada e, assim, fez parte da segunda turma do curso. Em 1965, ainda cursando o secundário, foi aprovada no concurso estadual para professor. Com sua aprovação, iniciou sua vida profissional, exercendo ativamente a sua função professoral, buscando aperfeiçoar os seus métodos de ensino por meio dos treinamentos pedagógicos oferecidos pelo Estado. Mostrou-se, então, contra o uso dos castigos físicos como recurso disciplinador e a favor de didáticas diferenciadas que facilitassem o aprendizado dos alunos.

Sua atuação foi refletida no reconhecimento dos seus colegas de trabalho, sendo respeitada e considerada por todos à sua volta. Indício disso revela-se na insistência da sua diretora para que protelasse a sua aposentadoria, e no convite de uma colega de trabalho para que a ajudasse a fundar uma "escolinha de educação infantil", particular, para crianças da cidade. Mais uma vez, assumiu o compromisso professoral participando ativamente e até encabeçando todos os eventos estudantis ali vivenciados. Sobre essa experiência, ela tem um acervo rico em fotografias que mostram toda a sua atuação em cada um desses eventos. São fotos que trazem lembranças dos desfiles cívicos e das homenagens que lhe foram prestadas. Após essa vida de dedicação ao universo escolar, acreditando que "a educação é o único caminho para a formação de bons cidadãos”, atingiu, no passar do tempo, um cansaço físico que a fez abrir mão do convívio escolar, aposentando-se, definitivamente, aos 82 anos.

Como se pode destacar, Isabel Doraci Cardoso não é uma pessoa ilustre, não assumiu postos de destaque no cenário político e/ou educacional, não escreveu nada que a consagrasse no plano intelectual, nem tampouco se destacou em sua vida de professora. Para os membros do grupo de historiadores ingleses da history from below, ela seria uma pessoa simples. E é justamente na condição de pessoa simples que a percebo, e percebo tal qual Eric Hobsbawn (1998, p. 8), para quem as pessoas simples “[...] são os principais atores da história. O que fazem e pensam faz a diferença". Tal máxima foi utilizada no prefácio de seu livro "Pessoas extraordinárias: resistência, rebelião e jazz", no qual ele contempla temas e sujeitos que dão a ver como pessoas comuns fazem parte dos fatos sociais e como estes pesam sobre os rumos e destinos históricos.

Por certo não se pode esperar grandes feitos, tal qual o dos heróis, mas, como já insinuado, percebê-los em suas experiências cotidianas e, mais que isso, contemplá-los na escrita da história parece uma ação importante por parte dos historiadores, uma vez que tais experiências revelam nuances, que se não forem vistas pelo ângulo "dos de baixo" como diria Sharpe e o próprio Thompson, não será possível perceber e compreender determinados fatos sociais. Sharpe (1992, p. 53-54) considera que, "[...] oferecendo essa abordagem alternativa, a história vista de baixo abre a possibilidade de uma síntese mais rica da compreensão histórica, de uma fusão da história da experiência do cotidiano das pessoas com a temática 
dos tipos mais tradicionais da história". E complementa, de maneira muito comprometida, quando afirma que, mesmo privilegiando as pessoas simples, não se pode dissociar as suas vidas da estrutura social e do poder social, sob o risco da fragmentação da escrita da história.

É justamente sob essa perspectiva, a de associar a vida de um sujeito simples (Isabel Doraci Cardoso) a uma estrutura social mais ampla (História da Educação), que tomo sua narrativa como fonte e busco nela elementos que revelam aspectos da educação em Sergipe. Nesse sentido, os pontos por ela ressaltados, mais do que revelar uma verdade, ou mesmo elementos que agreguem valor a uma história narrada a partir de documentos oficiais, indicam um modo de conceber a história, um modo de entendê-la, atentando para o fato de que os sujeitos também são responsáveis por seus destinos e por sua história, que é resultado de uma série de circunstâncias que não estão e não poderiam ser ditadas por documentos oficiais e que, necessariamente, estão imbrincados numa história coletiva e por isso se podem revelar.

\section{A educação escolar primária}

Foi na década de 1920 que o Brasil sentiu a necessidade mais premente de mudar o quadro de analfabetismo que o caracterizava. A essa época, segundo Nagle (1974), o país contava com $80 \%$ de analfabetos, o que ele considerou a "[...] grande vergonha do século, no máximo ultraje de um povo que vive a querer ingressar na rota da "moderna civilização" (NAGLE, 2001, p. 149). Diante de tal cenário, movimentos em favor da expansão da escola e da formação de professores foram pensados e postos em prática, reverberando, inclusive, no campo, o que ficou conhecido como "entusiasmo pela educação" e "otimismo pedagógico".

Ainda segundo Nagle, em nome do nacionalismo, a educação primária foi pensada e sua expansão constou como uma forma de sua divulgação. Bem assim, como forma de aprofundar a mudança iniciada ainda no século XIX, desponta, com toda força, na década de 1930, o "movimento da escola nova" que, associado ao método intuitivo, tinha objetivos nobres, tais como

[...] exercícios destinados a formar o hábito de pensar e dizer com 'desembaraço e correção', descrevendo as sensações experimentadas no contato com objetos existentes, isto é, traduzindo por meio da linguagem as sensações provenientes da visão, da audição, do olfato e do tato, com o objetivo de garantir que as ideias [adquirissem] um símbolo falado, a palavra que as designa (VALDEMARIN, 2006, p. 79, grifo do autor).

Na análise de Vidal (2000, p. 498), para os escolanovistas, o aluno deveria assumir “[...] soberanamente o centro dos processos de aquisição do conhecimento escolar: aprendizagem em lugar de ensino"; e, com tal intuito, o movimento se expandiu por todo o País, o que incluiu Sergipe, embora não com o mesmo ritmo. Vale registrar que o Estado de Sergipe, nos anos 1930 e 1960 (período em que nossa personagem começou, interrompeu, continuou e depois concluiu seu processo formativo), foi marcado por uma série de melhorias em termos educacionais; isso se se levar em consideração os incentivos do governo federal através do Instituto de Estudos Pedagógicos (Inep), o número de escolas isoladas existentes, a implementação dos grupos escolares (cerca de 43 entre 1930 e 1960) e das escolas rurais, que 
somaram 218 no período entre 1948 e 1951, para além de duas escolas normais rurais no mesmo período, que foram implantadas em pontos estratégicos do Estado de Sergipe.

Em contrapartida, se se considera a qualidade dos prédios escolares, bem como ensino ministrado, o que pressupõe a formação dos professores e os materiais didáticos, a história ganha outra feição e as conclusões enveredam por seara oposta. Foi perseguindo tal lógica histórica e em busca de uma história da educação sergipana vista de baixo que foi elaborado o projeto "Memória oral da educação sergipana", que teve por objetivo compreender os modos de educar, a cultura escolar e as práticas escolares desenvolvidas nas escolas dos territórios que compõem o Estado de Sergipe, tomando como objeto de análise a narrativa acerca da história de vida de educadores aposentados do Estado. Com tal intuito, foram ouvidos 145 professores, com idade entre 55 e 103 anos, que estudaram e ensinaram no Estado de Sergipe ${ }^{2}$. As escutas revelaram mais do que se objetivou, pois tornaram visível também elementos da história da educação sergipana que vão além da história oficial e que possibilitaram, como assinala Sharpe (1992, p. 53-54), “[...]uma síntese mais rica da compreensão histórica".

Assim, a partir da metodologia da história oral, segundo Alberti (2006), foi possível perceber que as mudanças em função da modernização, que no período de 1930 a 1960, era apresentada pela expansão da educação pelos grupos escolares e escolas rurais, não esteve condicionada apenas aos interesses políticos e aos recursos destinados mas também a sujeitos escolares e ao meio onde estes viviam. Isso porque as relações por eles estabelecidas envolvem escolhas, invenções, rupturas, adaptações, obstinações, dentre outros elementos que, para além de comporem os atos individuais, envolvem o coletivo. Nesse sentido, pode-se afirmar que, ao lado das escolas pensadas, planejadas e criadas em função da modernização da educação, o que se subentende prédio com mais de uma sala, professores formados, material didático, métodos de ensino condizente com o que se devia ensinar, estavam, também, as escolas cujas práticas escolares em muito destoavam do prescrito. É o que comenta Santos (2016) uma das pesquisadoras do referido projeto:

\footnotetext{
${ }^{2}$ As entrevistas foram realizadas por 10 alunos de Iniciação Científica durante os anos de 2011 e 2015. Estes, de acordo com a delimitação espacial de cada projeto, viajaram por todas as cidades e utilizando de táticas, a exemplo de pesquisas em Secretarias de Educação, de conversas informais nas Praças Centrais de cada cidade, conseguiram mapear os professores mais antigos ou de maior representatividade local. Uma vez identificados os sujeitos e se mostrado dispostos a concederem não só a entrevista mas também autorizar a sua publicação, os alunos davam início às gravações, respeitando as condições físicas do entrevistado e a fluidez da narrativa. As entrevistas tiveram duração mínima de trinta minutos e máxima de oito horas de filmagem. Ao término das gravações, os professores entrevistados assinaram um Termo de Consentimento, no qual autorizavam a publicação do conteúdo das entrevistas. Uma vez gravadas/filmadas, as entrevistas foram transcritas pelos alunos de iniciação científica. Eles utilizaram a ferramenta Microsoft Word e respeitaram traços culturais e linguísticos da narrativa do entrevistado, mesmo que para isso fossem revelados erros semânticos e sintáticos. Vale ressaltar que o fato de terem sido professores não isenta o vocabulário de conter erros gramaticais, pois a ausência de uma formação que fosse para além do ler, escrever e contar contribuiu para que as gírias, os regionalismos, as repetições e os vícios de linguagem prevalecessem no léxico de muitos dos professores, o que pode contribuir com possíveis estudos voltados para a área da linguagem. Tais elementos também foram mantidos com o intuito de preservar a natureza da narrativa e tentar garantir as condições de legitimidade e fidelidade na produção do documento. A entrevista aqui utilizada como fonte e objeto de estudo foi realizada por Rony Rei do Nascimento Silva que, à época aluno de iniciação científica, foi um dos mais destacados alunos vinculados ao projeto. A ele o meu agradecimento e a minha estima e admiração pelo caminho trilhado.
} 
Contudo, foi possível perceber interferências culturais que acabavam indo de encontro ao prescrito, a exemplo do uso de castigos físicos no Grupo Escolar Tobias Barreto, na década de 1950. Além desses, atividades não previstas pela legislação, como a permanência do aluno, mesmo que aprovado, na última série primária de escolas graduadas, como nos Grupos Tobias Barreto e Fausto Cardoso, evidenciam estratégias dos professores e alunos que partiram das necessidades desses que, apesar de motivados a prosseguir nos estudos, eram privados, por condições econômicas e educacionais, de ingresso no ensino secundário (SANTOS, 2016, p. 145).

A permanência nas escolas estava, nesses casos, relacionada à falta de séries subsequentes nas escolas do município, ficando os alunos sem alternativa de estudo, a não ser repetir o ano mesmo sem ter sido reprovado. Santos (2016) ainda acrescenta, a partir dos estudos de Faria Filho sobre os grupos escolares mineiros, e dos de Rosa Fátima de Souza em São Paulo:

Assim, foi possível identificar que ao mesmo tempo em que os grupos escolares foram concebidos nos discursos políticos como 'palácios', 'templos de saber', 'vitrines da república', eles também foram representados pelas narrativas como 'escolas simples', 'escolas de difícil acesso', 'escolas tradicionais'. Do mesmo modo, escolas isoladas e de inciativas particulares foram consideradas ora como 'escolas não ideais' e 'escolas precárias', ora como 'escolas muito boas' e 'escolas necessárias'. Tais sentidos, por vezes contraditórios, podem ser concebidos como frutos de '[...] razões, códigos, finalidades e destinatários particulares' (CHARTIER, 1990) que moveram as representações produzidas pelos sujeitos. Deste modo, foi possível considerar que as representações dispostas nos documentos oficiais estiveram atreladas a razões políticas, que atendiam regulamentos legais e finalidades educacionais destinadas a um projeto republicano de educação. Em contrapartida, os sentidos atribuídos pelos professores entrevistados à expansão das escolas primárias foram movidos por experiências pessoais e do cotidiano, o que por sua vez envolveu condições de desenvolvimento cultural, social e econômico de sua região (SANTOS, 2016, p. 145-146, grifos do autor).

Assim também foram representadas as escolas pelas quais passou a sergipana Isabel Doraci Cardoso, cuja narrativa acrescenta um outro elemento importante para a compreensão da matrícula e do acesso ao ensino, bem como acerca das táticas usadas para garantir a inserção da criança no universo estudantil:

Não, eu pequena eu via meus dois irmãos que são mais velhos do que eu, irem pra escola, né? Eu também queria ir, mas não me aceitavam. Porque eu não tinha sete anos. Mas aí é quando tinha essa Escola Isolada e minha mãe me colocou

[...] É... não tinha nem nome, eu me lembro do nome da professora que era Pureza dos Reis. Agora não tinha nome, não. Acho que não. [...] aqui em Aquidabã. 
Era uma casa, uma salinha, uns bancos, uns banquinhos de tira. Outros alunos levavam uns tamboretinho. E era assim a escola, num era uma escola assim!... Mas a professora ensinava pelo menos o ABC, né? (CARDOSO, 2013).

Como pode ser percebido, a geração de Isabel Doraci também passou por situações em que a alternativa viável no processo de escolarização ficava aquém do minimamente ideal. Sobre o ensino nas Escolas Isoladas, ela rememora o modo como aprendeu e o método utilizado, bem como a sequência de escolas pelas quais passou e sobre o que ali era ensinado:

Ah, elas ensinavam, A-B-C. E ali tinha que a gente gravar, né? Tinha que gravar na memória. Depois dessa, antes de eu vim para o Milton Azevedo, eu fui pra outra escola, assim também Isolada. Era... o nome dela era Dom... Eu acho que era Ana, e o povo chamava de Donana. Eu acho que era pra chamar Dona Ana (CARDOSO, 2013).

Foi sobre a professora "Donana" que a representação mais forte ficou, pois a rigidez no ensino, caracterizada pelas ameaças, consideradas pela professora como sinal de autoridade escolar, foram por ela narradas como um mal superado, mas que desvenda o modo como a criança era tratada e como respondia aos apelos:

E essa, essa mulher ela era casquinha. Eu aprendi as letras do A-B-C todo, mas quando chegava no $\mathrm{C}$ eu não sabia dizer. 'Menina diga: A-B. Aí eu dizia: A-B-D.' E essa outra? 'Professora eu num sei'. Aí quando foi um dia ela disse: 'Amanhã, ou você vem dizendo o nome dessa letra ou você vai levar uma dúzia de bolo'. Que tinha palmatória, tinha régua. Mas eu cheguei em casa acabada da vida. 'Mamãe eu não vou mais pra aquela escola não. Porque amanhã se eu não souber dizer o nome dessa letra eu vou apanhar'. Minha mãe disse: 'Eu vou passar a noite todinha lhe ensinando'. Aí mamãe: 'quando saí amanhã dizendo assim: cê'. Aí eu fiz isso. Eu saí de casa dizendo cê, pra não me esquecer do nome. Quando cheguei na escola eu já cheguei dizendo: Professora, eu já sei o nome da letra, é cê. Ela disse: 'Que coisa boa, e não vai apanhar". Mas aí depois eu cismei, saí dessa escola. Aí depois foi quando veio o Milton Azevedo, aí eu emendei, aí com gosto de gás (CARDOSO, 2013).

Ela também revelou elementos da cultura material escolar e como esse tipo de escola se apresentava:

Não, era a mesma história. Salinha com os banquinhos, os caxãozinho os tamboretinho Agora depois eu fui pra uma escola mesmo do Estado, quando eu já tinha sete anos, mas ainda não era o Milton, né? Era Estadual, e o nome da professora era Ivanete (CARDOSO, 2013).

Ao mudar de escola, mesmo com expectativa de melhora, o espaço escolar seguia com os mesmos elementos "Era sala também, mas já era melhorzinha, já tinha uns 
banquinhos pra gente sentar certinho, tinha quadro, já era melhorzinha”. E acrescenta: "Bebia [água] numas... numas... numas moringas que tinha, ou era pote, num me lembro muito bem não. Agora no Grupo [Milton Azevedo] tinha aqueles bebedouros". Tais aspectos demonstram não somente a simples configuração de uma instituição escolar mas também o modo como uma geração de sergipanos foi formada. Se se considera todo o discurso escolanovista, acerca dos espaços escolares, que circulava à época, fica difícil entender como narrativas iguais a esta podem ser contadas. Por isso não se pode desconsiderar as diferenças entre o prescrito e o vivido.

Já sobre o método em que foi alfabetizada, ela revela procedimentos que vão desde a aprendizagem das letras, pela memorização, ao modo como estas eram entoadas foneticamente:

Era um ABC. Tinha um livrinho assim, bem fininho, pequeno, o ABC todo. A-B-C-D-E, num dizia efe não, era fê. Era mesmo que a música de Luiz Gonzaga, vixe quando ê, né? E era fê, gê, H,I, Ka, lê, mê... Era assim, agora que é moderno, e já não se diz mais o nome da letra não, é: me, é eme, né? Mas eu estudei o ê mesmo.

[...]

Ipi..Ipisi...Ipisilone. V w, ói que loucura, porque o nome da letra é dáblio, mas como ele vem depois do $\mathrm{w}$, aí se dizia $\mathrm{v} \mathrm{w}$. Num é? Porque o w é depois do v.

[...]

Não era erre mesmo... Rê, si, tê, u, vê, x e lá se vai.

[...]

Bom, era aprender a letra, o nome da letra. E quando... E outra coisa, pronto ela tava dando aula, no caso A-B, ela escondia assim: 'Que letra é essa?' E escondia o restante das letras, pra gente dizer salteado, como elas diziam, né? Aí dê, e escondia a outra, aí ji, que o jota era ji, né? Pra vê se decorou (CARDOSO, 2013).

Como se pode constatar, o método sintético, com suas vertentes fônica, alfabética e silábica, foi utilizado na alfabetização de Isabel Doraci, da mesma forma que se revelam procedimentos do método analítico associados à educação familiar:

Cartilha Analítica. Ainda hoje eu me lembro, ali pra aprender a soletrar, misericórdia. Era um sucesso! Meu pai não tinha paciência de ensinar, porque ele dizia assim, no caso, deixe eu me lembrar qual era a palavra, viu? Muro. Aí ele fazia: 'Me ô um rê o ró' eu dizia: Me ô um rê o ró, mas só dizia, munturo. Papai: 'Mas de onde vem esse munturo, agora praqui?'. Aí pronto, eu era assim muito sensível, ninguém podia me passar um carão que eu já chorava. Aí eu dava pra chorar e papai dizia: 'Olhe, eu num lhe ensino mais não'. Mamãe dizia: 'Venha pra cá que eu lhe ensino.' Minha mãe tinha paciência, ela dizia: 'Minha fia, bote na cabeça me ô mu rê o ró é muro, não é muturo!'. E era os ensino era assim; depois, quando aprendi a soletrar, aí já passei a dá lição de có. Lição de có, como é lição de có? Estudar em casa, decorar, decorar aquele pedaço todo que elas marcavam, pra chegar lá... Eu 
quando chegava lá, eu via tudo escrito na cara da professora. Era olhando pra ela e dizendo a lição toda de có. Era de quê? De História, de Geografia, de Ciência, tudo era decorado (CARDOSO, 2013).

Sobre como aprendeu a escrever nas escolas isoladas pelas quais passou, ela assim rememora: "Eu acho que cobria, nem me lembro direito. Acho que cobria, era cobria. Cobria. $\mathrm{E}$ as vezes a gente não sabia por onde começar e elas [as professoras] pegavam na mão, pra mostrar de onde começava a letra". Vale ressaltar que o procedimento de pegar na mão para guiar o aluno nas descobertas das curvas que cunhavam as letras, bem como orientá-lo na postura adequada para escrever, foi (e ainda é) muito utilizado no processo de alfabetização, e remete à caligrafia muscular divulgada pelo movimento escolanovista nos anos de 1930, com o objetivo de resolver o problema da letra inclinada e da escoliose, decorrentes, respectivamente, da miopia e da má postura que o aluno tinha ao escrever. "A importância de desenvolver a boa escrita era realçada pelo imperativo de formar o senso estético da criança, precioso à sua educação sentimental. O ensino da técnica, ainda, deveria proporcionar ao/à aluno/a hábitos de ordem e asseio e disciplina mental" (VIDAL, 1998, p. 1).

$\mathrm{O}$ asseio e o cuidado com o corpo também foram registrados como uma função da educação escolar primária, apregoada desde 1893 pelo regulamento do Serviço Sanitário em Sergipe. Doraci lembra com bastante clareza dessas exigências: "As unhas, as unhas. E quem quisesse fosse com as unhas sujas, que era palmatória nos dedos. Olhava, olhava...”. É bem certo que o imperativo das ações que desde o século XIX vinham ditando uma nova configuração escolar e, consequentemente, uma nova formação, também esteve presente, e foi revelado na narração do processo formativo de nossa personagem, uma vez que desenvolver nas crianças certas habilidades que as tornariam adultas capazes de mudar a sua realidade era objetivo da escola republicana, que tinha no trato higienista um aspecto crucial de mudança de mentalidade.

Não obstante, mesmo no Grupo Escolar Milton Azevedo, instituição que deveria seguir uma pedagogia moderna, registram-se elementos do método tradicional, cuja principal característica era a memorização, que, mais particularmente, estava associada ao ensino da Matemática, e, por extensão, à aplicação de castigo físico para quem errasse, por exemplo, a recitação da tabuada, como relembra Doraci:

A tabuada, $2+1=3,3+1=4$. Tinha que ser... Tinha que decorar, cada dia era uma casinha. $2+2$, no outro dia, era $2+1$, no outro dia, era $3+1$. Quando terminava a de dez, aí já ia pra diminuir. $10-1=9,10-2=8$ e aí lá vai...

[...] E tinha também a sabatina, quando a gente sabia e o colega sabia, dava bolo em quem não sabia. Era um método triste! Ave Maria! Quando eu comecei a trabalhar, ainda bem que eu já comecei já não existia esse negócio de régua, nem de palmatória, não. Mas aí levei a minha vida estudando assim, né? Decorando. Mas com esse... Com essa atrapalhação toda, foi muito bom. Que ainda hoje eu me lembro, né? Agora terminei o quarto ano primário com quartoze anos (CARDOSO, 2013, grifo nosso).

Como visto, o presente acaba sendo também um elemento de valorização da formação do passado. Nessa perspectiva, e a comparação entre a escola de "ontem e a de 
hoje" acaba sendo um imperativo analítico, com ganho de causa para os métodos mais suaves e menos sofridos, que remetem a um outro imperativo categórico, traduzido no fato de que a memória confere legitimidade social à história da educação na medida em que relaciona a história individual com sua trama coletiva. Em sua narrativa, que muito revela sobre a representação e o juízo de valor, Doraci atribui à sua educação em detrimento da educação contemporânea:

É, aí já entrava em verbo, as classes gramaticais, sabe? Era... Era um livro bom também, não resta dúvida, não é? Aí a gente tinha que aprender a conjugar o verbo, presente do indicativo, passado, futuro, num sei o quê... Condicional, perfeito, imperfeito. Sei lá, ói era tanta... E tinha que saber tudo isso. Mas, eu...eu acho assim, que diz que quem aprende decorando não grava. Grava! Mas decorou, como é que não grava? Que eu acho que, hoje em dia, os alunos sabem menos do que eu sabia no passado. Que eu não...Eu só tenho o pedagógico, segundo grau, né? E eu não me troco hoje em dia por umas certas formaturas. Entendeu, como é? Que eu... Meu Deus, a gente hoje, professor assim formado, né? Faculdade tudo, tão falando tão errado. Ói: 'Quem de uma escapa, cem ano veve!' Eu já escutei isso. 'Quem de uma escapa, cem ano veve'. Meu Deus, o nome do verbo é veveêr, né? Que pelo o que eu sei, o nome do verbo é viver, né? (CARDOSO, 2013).

É certo que essa avaliação está condicionada a erros individuais; entretanto, é o suficiente para que seu julgamento e sentença sejam proferidos e revelados com ganho de causa para a educação que recebeu. É possível desvelar também que elementos do método intuitivo/concreto, embora este já não mais fosse discutido no cenário nacional, foram ressaltados na narrativa sobre sua educação primária:

Geografia era pra falar sobre a Terra, sobre os acidentes geográficos, e ainda a gente tinha que fazer de barro, que hoje a gente chama argila, né? Mas era barro mesmo, desse barro de olaria. A gente ia pra olaria, pegar um pouco de barro dessa olaria, e fazer uma tábua, os acidentes geográficos, assim fazer um vulcão, fazer montanha, depois pintar, rio. Um bom ensino! Num é, não? (CARDOSO, 2013)

Um outro componente da educação escolar primária da nossa personagem está atrelado aos castigos físicos imputados à sua geração; mas estes ela diz não haver sofrido porque era uma "menina comportada". Mesmo assim, foi capaz de relembrar ainda alguns deles como: "Ficar de pé, apanhar de régua, de palmatória". E ainda arremata: "Bom, quando era muito indisciplinado! Eu mesma nunca recebi. O castigo que eu ia receber era levar bolo, se eu não levasse o nome da letra cê. Mas eu mesma nunca... Nunca fui aluna indisciplinada.”. Também relembra os motivos pelos quais o castigo era aplicado:

Eu tinha cada colega, menino, que era um serviço! Agora eu, num é porque eu quero dizer não, eu nunca fui aluna desobediente. Eu sempre... onde a professora me colocava eu ficava. Porque tem alunos que brigam pra tá na frente, pra tá no banco da frente. Não, eu onde ela me botava, eu ficava, embora eu já tinha problema de vista; às vezes, eu escrevia errado porque eu não enxergava bem o quadro. Mas eu tinha vergonha de dizer (CARDOSO, 2013). 
A ameaça do castigo também esteve condicionada ao aprendizado das poesias: "Tinha que decorar também a poesia. Rum, e não decorasse! A escola, que era bem, era bem divertida! Agora quem tracejasse, o bolo comia na régua". E apesar de considerar a escola divertida, ela indicia que o perfil da professora a tolheu de expor suas limitações para aprender, o que, mesmo à época, constituía um problema, haja vista que a figura do professor pensada pelo movimento escolanovista congregava a habilidade de conduzir o aluno no processo de aprendizagem.

As obrigações cívicas e o comportamento disciplinar também foram rememorados: "Bem, nas escolas isoladas, eu num aprendi nada não, porque eu ainda era muito pequena. Agora, no Milton Azevedo, tinha que cantar o Hino Nacional todos os dias. Na frente do Grupo, e quando terminava a aula, saía cantando. E ai do aluno que não cantasse o Hino Nacional!". E mais: “Cantava Hino Nacional, Hino da Independência, Hino à Bandeira, [...] o hino nacional era todos os dias. Na entrada e na saída." Sobre o modo como eram os desfiles alusivos à independência do Brasil, ela ressaltou: "A gente marchava na rua. Agora só com um tambor e uma caixa. Mas fazia festa. Não quero saber... um tambor e uma caixa. Era..." A educação cívica também foi lembrada em associação à educação física sem, no entanto, fazer qualquer alusão ao militarismo:

A Educação Física era com um calçãozinho. No dia da Educação Física, já saía de casa com a saia e o calção por baixo com elástico na perna. E a Educação Física era pra fazer, sei lá.... era, tinha o professor, apitava e a gente já sabia o que é que ia fazer. Que teve até um sete de setembro, tinha jogos também, um sete de setembro que a minha sala que eu estudava, aí fez uma demonstração na praça, assim de jogos... 'Vixi Maria', eu quase morro de alegria, porque eu fui fazer essa apresentação na praça, eu toda de calçãozinho, aí era muito bom! (CARDOSO, 2013).

Sobre suas professoras, a memória também foi ativada:

Ah, no [grupo escolar] Milton, deixe eu me lembrar aqui, viu?... no Milton a primeira... A diretora de quando inaugurou e de quando eu entrei, o nome dela era Zuleida... Zuleida Nunes Cardoso. E a minha professora era, peraí! deixe eu me lembrar aqui agora. Porque eu tive, é que sempre mudava... Tônica. Ói que nome, né? Tônica! [...] Pronto, aí depois daí, aí foi muitas... É... eu estudei com Tônica, Abigail Melo, Zilda Carvalho. Essa foi do quarto ano. Zilda Carvalho, e tinha outras professoras. Mas as que eu passei mesmo foi por essas (CARDOSO, 2013).

De qualquer modo, a narrativa também revela os lapsos e as estratégias da memória, na medida em que arregimenta todas as áreas e as sintetiza de modo a revelar apenas o que importou. Como no caso em que rememorou as disciplinas e os seus livros didáticos; ela foi lacônica, destacando mais o modo de ensinar da professora do que os conteúdos que foram aprendidos: 
Era Aritmética, Ciência, História do Brasil, Geografia, por enquanto até aí, né? Até o primário, era esses os livros. E aí a gente tinha que decorar a lição, por exemplo, o descobrimento do Brasil, a gente tinha que decorar, né? Elas marcavam daqui até aqui, o Brasil foi descoberto em 1500, por Pedro Álvares de Cabral, e... e tinha que dizer assim, olhando pra cara dela (CARDOSO, 2013).

Um outro elemento, trazido por esse tipo de narrativa, e que em muito contribui para o entendimento de aspectos específicos da educação, como, por exemplo, a reprovação, a evasão, e a indisciplina, é a lembrança sobre determinadas práticas escolares que não constam nos normativos institucionais. O exemplo a seguir congrega bem alguns dos sintomas que foram/são sofridos na infância e que reverberam na vida adulta:

Como é que pode escrever com um lápis desse? Aí eu só chegava em casa chorando. 'Mamãe, amanhã eu num vou não, porque a professora disse que esse lápis não presta mais'. am... Aí mamãe dizia assim: 'Diga a ela que lhe dê um!', porque quando eu tiver o dinheiro eu compro, mas enquanto eu não tiver você vai com esse mesmo, eu não vou comprar fiado, sem pagar'. Aí terminou... mamãe me tirou da escola, mas a diretora era beleza! Mamãe falou com a diretora e ela disse: 'De jeito nenhum, ela vai continuar indo pra escola'. Eu ainda perdi uma semana de aula, mas aí Deus me ajudou... quando eu voltei tiraram ela daqui e carregaram ela pra Aracaju. Aí pronto, aí eu não tive mais problema com ninguém. Só tive essa, que tive esse problema (CARDOSO, 2013)

Uma outra feição que a narrativa revela, e que está além da apreensão pelos documentos escolares, é a relação entre professor-aluno-professor e as distintas formas que esta pode assumir. Tomemos, por exemplo, o pronunciamento seguinte:

Pra mim era. Só... só essa Tônica que eu não gostei muito dela. Porque ela era assim... Porque num tem professor que gosta de puxar saco de um aluno, porque as vezes é rico, num é? Eu num... eu num... Deus me livre eu nunca fiz isso. Então, essa professora, rum... Tinha uma turminha de meninas que os pais eram lá do comércio, os pais podiam, o meu era pobre, não é? Aí, elas pintavam e bordavam aí a professora brigava comigo. 'Isabel!' (CARDOSO, 2013).

Entre os ditos e os não-ditos, a narrativa insinua os mecanismos utilizados pelos professores para o distinto tratamento dado aos alunos, independente da apreensão dos conteúdos ministrados. Vale ressaltar que, embora ela estivesse tratando de seu caso especifico, indicia-se com essa evocação, comportamentos que, mesmo desprezíveis, faziam parte das práticas professorais e que por serem atos cometidos na fase da infância, ecoam pelas lembranças até a fase adulta. A esses sintomas, psicólogos e psicoterapeutas têm dedicado estudos com o objetivo de evitarem, em deriva de tal repercussão, o baixo rendimento e a evasão escolar. 
Como observado, as normas e as práticas, como já anunciava Julia, não podem ser concebidas e entendidas sem os agentes escolares e suas ações. Isso foi ratificado no discurso de Doraci, que rememorou nomes, como os daqueles professores do primário os quais citou nominalmente. Nessa lógica, a memória acionada revela não somente situações de constrangimento de uma aluna mas também elementos experienciados de um habitus professoral que pode não ser pontual, considerando-se o fato de que preconceitos povoam a cultura brasileira, e a escola acaba sendo um lócus privilegiado para sua demonstração, e que, por isso, o exame dessa experiência pode propor novos problemas de investigação, como sugere a epígrafe deste artigo.

\section{Considerações finais}

Como exposto na narrativa, elementos dos métodos de ensino, do higienismo, de civismo, dos microcosmos e microclimas criados no ambiente escolar, dentre outros aspectos da educação sergipana/brasileira, também podem ser compreendidos a partir da história de um sujeito escolar, em que pese ser a memória repleta de lembranças e passível de esquecimentos. (BOSI, 1995). Tal ideia perpassou o que este estudo procurou responder. E, como demonstrado, as evidências, embora "incompletas e imperfeitas", foram suficientes para que o diálogo entre hipótese e evidência, como sugeriu Thompson (1981), fosse estabelecida, visando ao conhecimento histórico.

Por tal narrativa, pôde-se apreender também, tanto a potencialidade da metodologia da história oral quanto o resultado para a escrita da história, quando a ela se associam os estudos biográficos. Isso porque ao revelar-se em sua individualidade, Isabel Doraci Cardoso expõe uma geração e suas vivências, tal qual fez George Duby ao analisar o manuscrito que descreve a vida de "Guilherme Marechal, ou O melhor cavaleiro do mundo" (1984), que revelou o coletivo, a partir de um sujeito. A ele só interessou o individual quando este informou sobre o geral. Assim também, a partir da biografia representativa, alargaram-se os espectros da Escola dos Annales e se gerou uma série de adeptos a esse modo de escrever a história.

Ao analisar esse trabalho de Duby e o de Carlo Guinsburg e seu moleiro, em "O queijo e os vermes", do qual deixa claro ser a personagem escolhida a síntese de várias outras, e em que, a partir do "estudo de caso", ele pôde entender a inquisição e os seus desdobramentos, Avelar (2010) assim conclui:

Uma escrita biográfica revelar-se-ia, portanto, um lócus privilegiado, não mais para um acesso ao universal como imaginava Dilthey, mas para revalorização dos atores sociais, alargando nossa compreensão do passado sem tomá-lo como uma unidade dada e coerente, mas como um campo de conflitos e de construção de projetos de vida (AVELAR, 2010, p. 170).

Nesse sentido, atentar para a história de vida de Isabel Doraci Cardoso e, dentro dela, a sua formação, é considerar não somente que ela representa uma geração mas também que, a partir de sua história, se pode entender aspectos da história da educação sergipana, pois o seu "projeto de vida" revela nuances que legislações, reformas escolares, regulamentos e 
regimentos não mencionam, haja vista que, por mais que o prescrito sirva de molde para as ações dos sujeitos, neste caso, escolares, há, no vivido, uma pluralidade de circunstâncias que pesam na estrita execução das normas preestabelecidas e que delas destoam e, por conseguinte, configuram, condicionam e contribuem com a escrita da história.

\section{Referências}

ALBERTI, Verena. História oral: a experiência do CPDOC. Rio de Janeiro: Editora da Fundação Getúlio Vargas, 1990.

ALBERTI, Verena. Ouvir contar: textos em história oral. Rio de Janeiro: Editora da Fundação Getúlio Vargas, 2004.

ALBERTI, Verena. De "versão" a "narrativa" no manual de história oral. Revista História Oral, v. 15, n. 2, jul./dez. 2012.

AVELAR, Alexandre de Sá. A biografia como escrita da história: possibilidades, limites e tensões. Dimensões, Espírito Santo, n. 14, p. 157-172, jan./dez. 2010.

BOSI, Ecléa. Memória e sociedade: lembrança de velhos. 4. ed. São Paulo: Companhia das Letras, 1995.

CARDOSO, Isabel Doraci. Entrevista. Aquidabã (Sergipe), 10 maio 2013. (concedida a Rony Rei do Nascimento Silva).

FARIA FILHO, Luciano Mendes de; GONÇALVES, Irlen Antônio; VIDAL, Diana Gonçalves; PAULILO, André Luiz. A cultura escolar como categoria de análise e como campo de investigação na história da educação brasileira. Educação e Pesquisa, São Paulo, v. 30, n. 1. p. 139-159, jan./abr. 2004. https://doi.org/10.1590/S1517-97022004000100008

HOBSBAWM, Eric. Pessoas extraordinárias: resistência, rebelião e jazz. Tradução Irene Hirsch. São Paulo: Paz e Terra, 1998.

JULIA, Dominique. A cultura escolar como objeto histórico. Revista Brasileira de História da Educação, Campinas, v. 1, n. 1, p. 9-44, jan./jun. 2001.

BARRETO, Raylane Andreza Dias Navarro. Raphael Samuel e a história local. In: MESQUITA, Ilka Míglio de; VALLE, Ione Ribeiro; CARVALHO, Rosana Areal. FARIA FILHO, Luciano Mendes de (Org.). Nas dobras de clio: história social e história da educação, Belo Horizonte: Mazza, 2014.

NAGLE, Jorge. Educação e sociedade na Primeira República. Rio de Janeiro: DP \& A Editora, 2001.

SANTOS, Laísa Dias. Por uma história vista de baixo: As escolas primárias dos territórios centro e sul sergipano (1930-1960). 2016. 170f. Dissertação (Mestrado em Educação) Programa de Pós-Graduação em Educação, Universidade Tiradentes, Aracaju, 2016.

SHARPE, Jim. A história vista de baixo. In: BURKE, Peter (Org.). A escrita da história: novas perspectivas. Tradução Magda Lopes. São Paulo: Editora UNESP, 1992.

OLIVEIRA, Marcus Aurélio Taborda. O pensamento de Edward Palmer Thompson como programa para a pesquisa em história da educação: culturas escolares, currículo e educação do corpo. Revista Brasileira de História da Educação, São Paulo, v. 8, n. 16, p.147-169, jan./abr. 2008. 
THOMPSON, Edward Palmer. The poverty of theory and other essays. London: Merlin, 1978.

THOMPSON, Edward Palmer. A miséria da teoria - ou um planetário de erros. Tradução de Waltensir Dutra. Rio de Janeiro: Zahar, 1981.

VALDEMARIN, Vera Teresa. O método intuitivo: os sentidos como janelas e portas que se abrem para um mundo interpretado. In: SAVIANI, Dermeval; ALMEIDA, Jane Soares de; SOUZA, Rosa Fátima de; VALDEMARIN, Vera Teresa (Org.). O legado educacional do século XIX. 2. ed. Campinas: Autores Associados, 2006.

VIDAL, Diana Gonçalves. Da caligrafia à escrita: experiências escolanovistas com caligrafia muscular nos anos 30. Revista da Faculdade de Educação, São Paulo, v. 24, n. 1, jan./jun. 1998.

Escola nova e processo educativo. In: LOPES, Eliane Marta Teixeira; FILHO, Luciano Mendes de Faria; VEIGA, Cynthia Greive (Org.). 500 anos de educação no Brasil. Belo Horizonte: Autentica, 2000. 